\title{
Kejadian Anemia pada Siswa Sekolah Dasar
}

\author{
Anemia Incidence among Elementary School Students
}

\author{
Saifuddin Sirajuddin*, Masni**
}

\begin{abstract}
*Program Studi Ilmu Gizi Fakultas Kesehatan Masyarakat Universitas Hasanuddin, **Fakultas Kesehatan Masyarakat Universitas Hasanuddin
\end{abstract}

\begin{abstract}
QAbstrak
Anemia gizi besi masih merupakan masalah kesehatan masyarakat dengan prevalensi pada anak 5 - 12 tahun sebesar $29 \%$ di Indonesia dan di Kota Makassar sebesar 37,6\%. Penelitian ini bertujuan untuk mengetahui faktor determinan (status kecacingan, status seng, kebiasaan sarapan pagi, pola konsumsi makanan sumber heme dan nonheme, pola konsumsi sumber makanan pelancar dan penghambat zat besi) terhadap kejadian anemia. Desain penelitian yang digunakan adalah potong lintang yang dilaksanakan pada bulan April - Juni 2014. Penelitian ini menggunakan desain potong lintang yang dilaksanakan pada siswa kelas 3 - 5 SD Negeri Cambaya Kecamatan Ujung Tanah Kota Makassar. Sampel sebanyak 120 siswa yang dipilih secara acak sederhana. Analisis data dilakukan secara univariat, bivariat dengan uji kai kuadrat dan multivariat dengan regresi logistik. Hasil penelitian menunjukkan faktor determinan kejadian anemia adalah status kecacingan (nilai $p=0,007$ ), kebiasaan sarapan pagi (nilai $p$ $=0,002$ ), pola konsumsi makanan sumber heme (nilai $p=0,004$ ), dan pola konsumsi sumber makanan penghambat zat besi (nilai $p=0,016$ ). Hasil analisis multivariat menunjukkan bahwa pola konsumsi makanan sumber heme $(\mathrm{OR}=5,09$ dan $95 \% \mathrm{Cl}=1,98-13,08)$ dan pola konsumsi sumber makanan penghambat zat besi $(\mathrm{OR}=4,53$ dan $95 \% \mathrm{Cl}=1,65-12,43)$ adalah determinan utama kejadian anemia gizi.

Kata kunci: Anemia, kecacingan, makanan sumber heme, makanan penghambat zat besi, pola konsumsi, kebiasan sarapan pagi
\end{abstract}

\section{Abstract}

Iron deficiacy anemia has been a public health problem with prevalence on 5 - 12 year old children worth $29 \%$ in Indonesia and $37.6 \%$ in Makassar. This study aimed to determine the determinant factors (worm status, zinc status, breakfast habit, consumption pattern of heme and nonheme source of food, consumption pattern of iron enhancer and inhibitor food) toward anemia incidence. The study used cross sectional design conducted in April - June 2014. The population was third to fifth grade students of Cambaya
State Elementary School at Ujung Tanah District, Makassar City. Sample of 120 students were selected randomly. Data was analyzed using univariate, bivariate with chi-square test, and multivariate with logistic regression test. The results showed that the determinant factors of anemia incidence were wormy status ( $p$ value $=0.007$ ), breakfast habits ( $p$ value $=0.002)$, consumption pattern of heme and non-heme source of food ( $p$ value $=0.004$ ), and consumption pattern of iron enhancer and inhibitor ( $p$ value $=0.016$ ). Multivariate analysis result showed that consumption pattern of heme (OR $=5.09$ and $95 \% \mathrm{Cl}=1.98-13.08)$ and consumption pattern of iron enhancer and inhibitor food ( $\mathrm{OR}=4.53$ and $95 \% \mathrm{Cl}=1.65-12.43$ ) was a major determinant of nutritional anemia.

Keywords: Anemia, wormy, heme source of food, iron inhibitor, food consumption, breakfast habit

\section{Pendahuluan}

World Health Organization (WHO) dalam Worldwide Prevalence of Anemia melaporkan bahwa total keseluruhan penduduk dunia yang menderita anemia adalah 1,62 miliar orang dengan prevalensi pada anak sekolah dasar 25,4\% dan 305 juta anak sekolah di seluruh dunia menderita anemia. ${ }^{1}$ Secara global, prevalensi anemia pada anak usia sekolah menunjukkan angka yang tinggi yaitu $37 \%$, sedangkan di Thailand $13,4 \%$ dan di India $85,5 \%$. Prevalensi anemia di kalangan anak-anak di Asia mencapai $58,4 \%$, angka ini lebih tinggi dari rata-rata di Afrika $(49,8 \%) .2,3$

Laporan Riset kesehatan dasar (Riskesdas) tahun 2013 menunjukkan bahwa anemia gizi besi masih meru-

Korespondensi: Saifuddin Sirajuddin, Program Studi Ilmu Gizi FKM Universitas Hasanuddin, Jl. Perintis Kemerdekaan Km.10 Tamalanrea Makassar 90245, No.Telp: 0411-585658,e-mail:saifuddin59@yahoo.com 
pakan masalah kesehatan masyarakat Indonesia dengan prevalensi pada anak usia 5 - 12 tahun sebesar 29\% dan di Kota Makassar sebesar 37,6\%.4 Dampak anemia bagi siswa sekolah dasar adalah dapat menyebabkan gangguan tumbuh kembang fisik, rendahnya daya tahan terhadap penyakit, tingkat kecerdasan yang kurang dari seharusnya, prestasi belajar/kerja dan prestasi olahraga yang rendah. Selain itu, anemia pada anak akan berdampak pada menurunnya kemampuan dan konsentrasi belajar, mengganggu pertumbuhan baik sel tubuh maupun sel otak sehingga menimbulkan gejala muka tampak pucat, letih, lesu dan cepat lelah sehingga dapat menurunkan kebugaran dan prestasi belajar. ${ }^{5}$

Anemia gizi besi dapat disebabkan oleh kurangnya asupan makanan yang mengandung zat besi dan konsumsi makanan penghambat penyerapan zat besi, serta penyakit infeksi. Selain itu, disebabkan oleh distribusi makanan yang tidak merata ke seluruh daerah, serta pola makan yang kurang beragam turut menunjang kurangnya asupan zat besi bagi tubuh. ${ }^{6}$

Anemia defisiensi besi dapat juga dipengaruhi oleh kebutuhan tubuh yang meningkat, akibat mengidap penyakit kronis, kehilangan darah karena menstruasi, dan infeksi parasit (cacing). Di Indonesia, penyakit kecacingan masih merupakan masalah yang besar untuk kasus anemia defisiensi besi karena diperkirakan cacing menghisap darah 2-100 cc setiap harinya. ${ }^{7}$

Masyarakat Indonesia masih banyak yang belum membiasakan sarapan. Padahal dengan tidak sarapan akan berdampak buruk terhadap proses belajar di sekolah, menurunkan aktivitas fisik, dan meningkatkan risiko jajan yang tidak sehat. Melewatkan sarapan pagi menjadi isu kesehatan masyarakat di dunia. Kebiasaan memberikan anak-anak sarapan merupakan salah satu faktor utama untuk menjaga kesehatan dan meningkatkan perilaku anak di sekolah. Hanya $27,7 \%$ dari orangtua siswa yang anaknya mengalami defisiensi besi menyadari bahwa sarapan dapat meningkatkan konsentrasi belajar di sekolah, sementara $22,4 \%$ dari orangtua siswa tidak tahu tentang pentingnya sarapan dan efeknya pada kesehatan anak. 8

Penelitian ini bertujuan untuk mengetahui faktor determinan kejadian anemia (status kecacingan, status seng, kebiasaan sarapan pagi, pola konsumsi makanan sumber heme dan nonheme, pola konsumsi sumber makanan pelancar dan penghambat zat besi) pada anak sekolah dasar.

\section{Metode}

Penelitian dilaksanakan di Sekolah Dasar Negeri (SDN) Cambaya, Kecamatan Ujung Tanah, Kota Makassar pada bulan April - Juni tahun 2014, menggunakan desain studi potong lintang. Populasi penelitian adalah siswa Sekolah Dasar Negeri Cambaya kelas 3, 4, dan 5 periode tahun ajaran 2014/2015 yaitu 179 siswa. Sampel yang digunakan sebanyak 120 siswa yang dipilih secara acak sederhana. Adapun kriteria inklusi, yaitu berstatus sebagai siswa aktif pada periode penelitian bersedia untuk diambil darah dan fesesnya.

Pengumpulan data dilakukan melalui serangkaian pengukuran. Status hemoglobin $(\mathrm{Hb})$ diukur dengan menggunakan alat Blood Hemoglobin Photometer. 9,10 Kriteria status $\mathrm{Hb}$ ditentukan berdasarkan standar yang telah ditetapkan oleh $\mathrm{WHO}$, anemia adalah $\mathrm{Hb}<11,5$ $\mathrm{g} / \mathrm{dL}$ untuk usia responden antara 10 - 11 tahun dan $\mathrm{Hb}$ $<12,0$ untuk responden berusia 12 tahun. Tidak anemia adalah $\mathrm{Hb} \geq 11,5 \mathrm{~g} / \mathrm{dL}$ untuk usia responden antara 10 11 tahun dan $\mathrm{Hb} \geq 12,0 \mathrm{gr} / \mathrm{dL}$ untuk responden berusia 12 tahun. Status kecacingan diukur dengan menggunakan metode kato katz untuk mengidentifikasi jenis cacing secara mikroskopis (cacing gelang, cacing cambuk, dan cacing tambang). ${ }^{11}$ Status seng ( $\left.\mathrm{Zn}\right)$ diukur menggunakan metode Kecap Smith, yaitu cara pengukuran dengan menilai tingkat ketajaman rasa yang dapat menggambarkan apakah seseorang mengalami defisiensi seng atau tidak. Zink sulfat akan merangsang molekul penerima rasa pada lidah sehingga ketajaman rasa dapat diukur. ${ }^{12}$ Kebiasaan sarapan pagi diketahui melalui wawancara perilaku makan pagi yang dilakukan oleh siswa secara rutin sebelum berangkat ke sekolah (kadang-kadang (2 - $3 \mathrm{kali} / \mathrm{minggu})$ dan sering (4 - 7 $\mathrm{kali} /$ minggu). Pola konsumsi makanan sumber heme (daging sapi, daging ayam, telur, udang, hati sapi, hati ayam, ikan segar, ikan teri, cumi-cumi, kerang, kepiting) dan nonheme (tempe, tahu, daun kelor, daun kacang panjang) melalui wawancara jenis makanan sumber zat besi yang dikonsumsi oleh anak yang ditinjau dari segi jenis dan frekuensinya dengan menggunakan food frequency questionnaire (FFQ) semi kuantitatif. Pola konsumsi pelancar (wortel, sawi, jeruk, pepaya, pisang) dan penghambat (teh, kopi, kangkung, ubi kayu) absorpsi zat besi melalui wawancara jenis makanan yang mengandung zat pelancar dan penghambat absorpsi besi yang dikonsumsi oleh anak yang ditinjau dari segi jenis dan frekuensinya dengan menggunakan food frequency questionnaire semi kuantitatif.

Analisis data secara univariat dilakukan terhadap semua variabel penelitian. Untuk melihat hubungan variabel independen dengan variabel dependen (bivariat), digunakan uji kai kuadrat. Sedangkan untuk melihat variabel independen yang paling berpengaruh terhadap variabel dependen, digunakan uji regresi logistik berganda.

\section{Hasil}

Siswa dengan jenis kelamin laki-laki dan kelompok usia 10 - 11 tahun lebih banyak berpartisipasi dalam penelitian ini (Tabel 1). Kejadian anemia lebih banyak 
ditemukan pada siswa yang mengalami kecacingan $(51,6 \%)$ dibandingkan yang tidak mengalami kecacingan $(27,6 \%)$. Status kecacingan memberikan pengaruh yang bermakna terhadap kejadian kecacingan (nilai $\mathrm{p}=$ 0,007) dan hasil uji phi menunjukkan bahwa variabel status kecacingan memberikan kontribusi sebesar 24,5\% terhadap kejadian anemia. Kebiasaan sarapan pagi dan pola konsumsi makanan sumber heme berpengaruh secara bermakna terhadap kejadian anemia (nilai $\mathrm{p}<0,05$ ) dengan kontribusi masing-masing variabel adalah $28,1 \%$ dan $26,6 \%$ (sedang). Pola konsumsi sumber makanan penghambat zat besi juga menunjukkan pengaruh terhadap kejadian anemia (nilai $\mathrm{p}=0,016$ ), besarnya kontribusi variabel pola konsumsi sumber makanan penghambat zat besi terhadap kejadian anemia berdasarkan uji $p h i=22,0 \%$, yang berarti bahwa kontribusinya lemah (Tabel 2).

Hasil analisis multivariat menggunakan uji regresi logistik berganda menunjukkan bahwa dari lima variabel penelitian yang disertakan dalam analisis yang menun-

Tabel 1. Distribusi Responden berdasarkan Karakteristik Anak

\begin{tabular}{llll}
\hline Karakteristik & Kategori & n & $\%$ \\
\hline Jenis kelamin & Laki-laki & 64 & 51,0 \\
& Perempuan & 56 & 49,0 \\
Umur (tahun) & $8-9$ & 35 & 29,2 \\
& $10-11$ & 72 & 60,0 \\
& $12-13$ & 13 & 10,8 \\
\hline Total & & $\mathbf{1 2 0}$ & $\mathbf{1 0 0 , 0}$ \\
\hline
\end{tabular}

jukkan nilai $\mathrm{p}<0,25$ pada analisis bivariat, terdapat empat variabel yang memberikan kontribusi yang bermakna (nilai $\mathrm{p}<0,05$ ), yaitu status kecacingan, kebiasaan sarapan pagi, pola konsumsi makanan sumber heme dan pola konsumsi sumber makanan penghambat zat besi. Analisis multivariat menunjukkan bahwa siswa yang positif kecacingan memiliki risiko 3,64 kali untuk anemia dibandingkan siswa yang tidak cacingan, siswa yang sarapan paginya kadang-kadang ( $<3 \mathrm{kali} /$ minggu) memiliki risiko 2,95 kali untuk anemia dibandingkan siswa yang biasa sarapan pagi, siswa yang pola konsumsi sumber heme-nya kadang-kadang memiliki risiko 5,09 kali dibandingkan siswa yang sering mengonsumsi makanan sumber heme, dan siswa yang sering mengonsumsi makanan penghambat zat besi memiliki risiko 4,53 kali dibandingkan siswa yang hanya kadang-kadang mengkonsumsi makanan penghambat zat besi. Berdasarkan hasil tersebut, terlihat bahwa variabel yang berkontribusi paling besar adalah pola konsumsi makanan sumber heme (Tabel 3).

\section{Pembahasan}

Anemia pada anak tidak hanya disebabkan oleh faktor asupan makanan, tetapi dapat juga disebabkan oleh faktor infeksi yang diderita anak, salah satunya adalah infeksi kecacingan. Hasil penelitian menunjukkan pengaruh status kecacingan terhadap kejadian anemia pada siswa, sebanyak $51,6 \%$ siswa yang terinfeksi cacing dan mengalami anemia, hasil uji statistik menunjukkan ter-

Tabel 2. Distribusi Responden Berdasarkan Faktor yang Berpengaruh terhadap Kejadian Anemia

\begin{tabular}{|c|c|c|c|c|c|c|c|}
\hline \multirow{2}{*}{ Variabel } & \multirow{2}{*}{ Kategori } & \multicolumn{2}{|c|}{ Anemia } & \multicolumn{2}{|c|}{ Normal } & \multirow{2}{*}{ Nilai $p$} & \multirow{2}{*}{ Nilai Phi } \\
\hline & & $\mathbf{n}$ & $\%$ & $\mathbf{n}$ & $\%$ & & \\
\hline \multirow[t]{2}{*}{ Status kecacingan } & Positif & 32 & 51,6 & 30 & 48,4 & $0,007 *$ & 0,245 \\
\hline & Negatif & 16 & 27,6 & 42 & 72,4 & & \\
\hline \multirow[t]{2}{*}{ Status seng } & Defisiensi & 29 & 42,6 & 39 & 57,4 & 0,498 & 0,062 \\
\hline & Normal & 19 & 36,5 & 33 & 63,5 & & \\
\hline \multirow[t]{2}{*}{ Sarapan pagi } & Kadang-kadang & 35 & 52,2 & 32 & 47,8 & $0,002^{*}$ & 0,281 \\
\hline & Sering & 13 & 24,5 & 40 & 75,5 & & \\
\hline \multirow{2}{*}{ Konsumsi sumber heme } & Kadang-kadang & 33 & 52,4 & 30 & 47,6 & $0,004 *$ & 0,266 \\
\hline & Sering & 15 & 26,3 & 42 & 73,7 & & \\
\hline \multirow[t]{2}{*}{ Konsumsi sumber nonheme } & Sering & 10 & 29,4 & 24 & 70,6 & 0,137 & 0,136 \\
\hline & Kadang-kadang & 38 & 44,2 & 48 & 55,8 & & \\
\hline \multirow[t]{2}{*}{ Konsumsi makanan pelancar Fe } & Kadang-kadang & 39 & 42,9 & 52 & 57,1 & 0,258 & 0,103 \\
\hline & Sering & 9 & 31,0 & 20 & 69,0 & & \\
\hline \multirow[t]{2}{*}{ Konsumsi makanan penghambat $\mathrm{Fe}$} & Sering & 37 & 48,1 & 40 & 51,9 & $0,016^{*}$ & 0,220 \\
\hline & Kadang-kadang & 11 & 25,6 & 32 & 74,4 & & \\
\hline
\end{tabular}

Tabel 3. Analisis Multivariat Determinan Kejadian Anemia

\begin{tabular}{|c|c|c|c|c|c|c|c|}
\hline Variabel & B & Wald & Df & Nilai p & OR & $95 \%$ & CI \\
\hline Status kecacingan (positif) & 1,294 & 8,117 & 1 & 0,004 & 3,64 & 1,49 & 8,87 \\
\hline Kebiasaan sarapan pagi (kadang-kadang) & 1,082 & 5,702 & 1 & 0,017 & 2,95 & 1,21 & 7,16 \\
\hline Pola konsumsi makanan heme (kadang-kadang) & 1,628 & 11,457 & 1 & 0,001 & 5,09 & 1,98 & 13,08 \\
\hline Pola konsumsi sumber makanan penghambat Fe (sering) & 1,512 & 8,639 & 1 & 0,003 & 4,53 & 1,65 & 12,43 \\
\hline Constant & $-3,661$ & 25,09 & 1 & 0,000 & 0,26 & & \\
\hline
\end{tabular}


dapat pengaruh yang bermakna dari status kecacingan terhadap kejadian anemia pada siswa (nilai $\mathrm{p}<0,05$ ), namun kontribusinya berdasarkan nilai phi $=0,245$ adalah lemah. Hasil ini konsisten dengan hasil analisis multivariat dengan uji regresi logistik yang menunjukkan nilai $\mathrm{OR}=3,64$, yang berarti bahwa, anak yang mengalami kecacingan berisiko menderita anemia 3,64 kali dibanding yang tidak kecacingan. Hal ini dapat dipahami karena cacing yang masuk ke dalam mukosa usus dapat menimbulkan iritasi dan peradangan mukosa usus. Pada tempat perlekatannya dapat terjadi perdarahan. Perdarahan inilah yang menyebabkan anemia. Infeksi rendah biasanya tidak memberikan gejala klinis yang jelas. Penelitian lain juga menunjukkan terdapat hubungan yang bermakna antara berat ringannya infeksi ascariasis dengan kadar $\mathrm{Hb}$. Semakin banyak telur cacing ascariasis (cacing gelang) dalam tubuh penderita, semakin rendah kadar Hb yang dihasilkan. Dengan kata lain beratnya infeksi ascariasis akan menjadi salah satu penentu kejadian anemia pada penderita. ${ }^{11}$

Tingginya kejadian kecacingan pada anak yang menjadi responden penelitian ini terkait dengan faktor lingkungan, yaitu keadaan higiene dan sanitasi lingkungan tempat tinggal anak, yaitu wilayah pesisir. Sebagaimana diketahui bahwa kebanyakan wilayah pesisir adalah wilayah dengan lingkungan yang kumuh dan padat penduduk. Selain itu, kebiasaan bermain dan perilaku anak- anak yang menjadi responden sangat berpengaruh dalam hal tingginya angka infestasi kecacingan di daerah ini. Seringnya anak bermain dan berinteraksi langsung dengan tanah, seperti tidak menggunakan alas kaki ketika bermain dan tidak mencuci tangan setelah bermain dan sebelum makan membuat parasit seperti kelompok soil-transmissed helminth dengan mudah melakukan invasi ke dalam tubuh anak-anak.

Penelitian Kharis dkk, ${ }^{12}$ menunjukkan bahwa kejadian kecacingan pada siswa sekolah dasar khususnya SDN Cempaka 1, tidak hanya dipengaruhi oleh salah satu aspek higiene yaitu kebersihan kuku, tetapi juga dipengaruhi oleh aspek sanitasi lingkungan dan aspek higiene perorangan lainnya, seperti kebiasaan mencuci tangan sebelum makan, sesudah bermain dengan tanah dan setelah buang air besar, dan selalu menjaga kebersihan lingkungan. Demikian halnya dengan penelitian Favour, ${ }^{13}$ di Nigeria yang mengungkapkan bahwa infeksi akan lebih berat kejadiannya pada wilayah dengan higiene dan sanitasi yang buruk.

Kebiasaan sarapan pagi merupakan faktor risiko kejadian anemia gizi pada siswa sekolah dasar. Siswa yang jarang atau kadang-kadang sarapan pagi yaitu 2 - 3 kali dalam seminggu berisiko mengalami anemia 2,95 kali dibanding siswa yang sering sarapan pagi. Survei Pergizi Pangan Indonesia tahun 2010 pada 35.000 anak usia sekolah dasar menunjukkan $44,6 \%$ anak yang sarapan kurang dari $15 \%$ kebutuhannya. ${ }^{14}$ Hasil penelitian ini didukung oleh penelitian Tandirerung dkk, 15 bahwa terdapat hubungan yang bermakna antara kebiasaan sarapan pagi dengan kejadian anemia pada murid SD Negeri 3 Manado. Penelitian Murphy, ${ }^{16}$ menunjukkan bahwa anak-anak yang melewatkan sarapan pagi lebih cenderung menunjukkan gejala anemia (defisiensi besi) seperti pucat, lesu, dan tidak bergairah.

Penelitian lain menunjukkan bahwa siswa perempuan yang sarapan secara teratur memiliki kadar $\mathrm{Hb}$, hematokrit (HCT), serum iron (SI), total iron bending capacity (TIBC) dan ferritin yang lebih tinggi dibandingkan dengan siswa yang tidak sarapan pagi dengan teratur, meskipun tidak terdapat perbedaan yang signifikan. ${ }^{17,18}$ Penelitian lain menunjukkan bahwa siswa yang melewatkan sarapan pagi memiliki prestasi belajar yang lebih rendah dibandingkan dengan siswa yang sarapan pagi. 19 Pemberian makanan yang bergizi pada anak usia sekolah sangat penting termasuk pemberian sarapan pagi. Kebutuhan gizi anak sekolah usia $6-12$ tahun berkisar antara $1.550-2.050 \mathrm{kkal}$. Sarapan pagi harus memenuhi sebanyak 20 - 25\% kebutuhan kalori sehari. Makan siang dan makan malam masing-masing $30 \%$, sedangkan makanan selingan dapat dilakukan dua kali dengan porsi masing-masing $10 \%$. Sarapan pagi erat kaitannya dengan kecerdasan mental, sarapan memberikan nilai positif terhadap aktivitas otak, otak menjadi lebih cerdas, peka dan lebih mudah untuk berkonsentrasi. Hal ini secara tidak langsung akan mendatangkan pengaruh positif terhadap anak sekolah dalam beraktivitas di sekolah. ${ }^{20}$

Sarapan atau kegiatan makan dan minum yang dilakukan sebelum jam 9 pagi dapat memenuhi $15-30 \%$ kebutuhan gizi harian sebagai bagian dari gizi seimbang untuk hidup sehat, bugar, aktif, dan cerdas. Banyak faktor yang menyebabkan anak sekolah dasar tidak biasa melakukan sarapan pagi, di antaranya adanya citra bahwa sarapan merupakan kegiatan yang menjengkelkan karena perlu bangun tidur lebih pagi agar terealisasi waktu untuk sarapan, pengetahuan orang tua rendah sehingga orang tua tidak menyiapkan sarapan dan keluarga tidak membiasakan sarapan. Faktor lain adalah untuk menjaga penampilan fisik. Karena itu sarapan merupakan salah satu perilaku penting dalam mewujudkan gizi seimbang. Pekan sarapan nasional (PESAN) yang diperingati setiap tanggal 14 - 20 Februari diharapkan dapat dijadikan sebagai momentum berkala setiap tahun untuk selalu mengingatkan dan mendorong masyarakat agar melakukan sarapan yang sehat sebagai bagian dari upaya mewujudkan gizi seimbang. ${ }^{8}$

Sarapan sehat setiap pagi dapat diwujudkan dengan bangun pagi, menyiapkan dan mengonsumsi makanan dan minuman pagi sebelum melakukan aktivitas harian. Sarapan yang baik terdiri dari pangan karbohidrat, pangan lauk-pauk, sayuran atau buah-buahan dan minu- 
man. Bagi orang yang tidak biasa makan kudapan pagi dan kudapan siang, porsi makanan saat sarapan sekitar sepertiga dari total makanan sehari. Bagi orang yang biasa makan kudapan pagi dan makanan kudapan siang, jumlah porsi makanan sarapan sebaiknya seperempat dari makanan harian.

Jenis dan jumlah makanan yang dikonsumsi juga turut berperan terhadap kejadian anemia. Seperti yang ditemukan pada penelitian ini bahwa, anak dengan pola konsumsi makanan sumber heme $\leq 3 \mathrm{kali} / \mathrm{minggu}$ berisiko untuk mengalami anemia sebesar 5,09 dibandingkan anak yang mengonsumsi makanan sumber heme $>3 \mathrm{kali} / \mathrm{minggu}$. Menurut Kisworini, ${ }^{9}$ anemia dapat disebabkan oleh kurangnya asupan zat besi dalam makanan, baik karena pola konsumsi makanan yang tidak tepat, kualitas dan kuantitas makanan yang tidak memadai, maupun karena adanya peningkatan kebutuhan zat besi. Masalah utama pemanfaatan zat besi oleh tubuh adalah rendahnya penyerapan di dalam usus. Penyerapan zat besi dipengaruhi oleh dua faktor, yaitu absorbsi besi heme dan nonheme yang menunjukkan keberadaan dua jenis zat besi yang berbeda di dalam pangan. Sumber heme pada pangan manusia adalah daging, ikan, dan unggas, sedangkan sumber nonheme adalah sereal, kacang-kacangan, sayur dan buah. ${ }^{21}$

Hasil penelitian menunjukkan bahwa jenis bahan makanan sumber heme yang paling sering dikonsumsi adalah ikan segar $(57,5 \%)$ dengan rata-rata skor 1,16 setiap hari, yang kadang-kadang dikonsumsi adalah daging ayam $(74,2 \%)$ dengan rata-rata skor 0,44 yang dikonsumsi 2-4 kali seminggu, sedangkan yang paling jarang dikonsumsi adalah hati sapi $(96,7 \%)$ dengan rata-rata skor $0,03<1$ kali sebulan. Hal tersebut karena sebagian besar pekerjaan orang tua responden adalah nelayan yang sebagian dari hasil tangkapan, yaitu ikan segar yang banyak mengandung zat besi heme, selain dijual juga diolah di rumah untuk dikonsumsi. Konsumsi ikan teri basah masih jarang dikonsumsi oleh responden meskipun pada wilayah penelitian ketersediaan ikan teri cukup banyak, namun sebagian besar responden tidak suka mengonsumsi ikan teri. Adapun jenis bahan makanan sumber zat besi nonheme yang paling sering dikonsumsi adalah tempe $(13,3 \%)$ dengan rata-rata skor 0,36 ( 2 - 4 kali dalam seminggu), dan tahu $(10,8 \%)$ dengan rata-rata skor 0,34 ( 2 - 4 kali dalam seminggu). Tempe mudah didapatkan dalam jajanan anak sekolah pada lokasi penelitian, sebagian besar jajanan yang dibeli di sekolah oleh anak adalah nasi kuning dengan lauk tempe, telur, dan tahu.

Penelitian ini juga menemukan bahwa pola konsumsi sumber makanan penghambat absorpsi zat besi berhubungan dengan kejadian anemia, namun menunjukkan kontribusi yang lemah (nilai $p h i=22 \%$ ). Hasil yang konsisten ditemukan pada hasil uji multivariat menggunakan uji regresi logistik yang menunjukkan nilai $p=0,003$ dengan besar pengaruh berdasarkan nilai OR $=4,53$. Hal tersebut berarti bahwa siswa yang sering mengonsumsi makanan penghambat absorbsi zat besi memiliki risiko untuk terkena anemia sebesar 4,53 kali dibandingkan siswa yang jarang/kadang-kadang mengkonsumsi makanan tersebut. Bioavailabilitas zat besi dalam makanan sangat dipengaruhi oleh faktor pelancar dan penghambat. Selain itu, bioavailabilitas zat besi juga terkait dengan zat besi heme dan nonheme yang memiliki nilai bioavailabilitas yang berbeda. Penelitian Briawan, ${ }^{21}$ menunjukkan bioavailabilitas zat besi (miligram) secara signifikan berhubungan dengan konsumsi daging sapi dan ayam $(\mathrm{r}=0,381)$ dan asupan vita$\min C(r=0,340)$ (nilai $p<0,05)$, namun, bioavailabilitas zat besi tidak berhubungan dengan asupan zat besi dan asupan protein (nilai $p>0,05$ ).

Jenis bahan makanan penghambat absorbsi zat besi yang paling sering dikonsumsi siswa adalah teh $(50,8 \%)$ dengan skor rata-rata 0,83 artinya dikonsumsi $5-6$ kali dalam seminggu, sedangkan yang paling jarang dikonsumsi adalah daun singkong $(94,2 \%)$. Jenis teh yang sering dikonsumsi oleh responden adalah minuman teh gelas, merupakan pangan jajanan yang saat ini sangat digemari oleh anak-anak serta masyarakat karena mudah didapatkan dengan harga relatif murah. Jenis makanan sumber penghambat absorbsi zat besi yang lain sangat jarang dikonsumsi karena kesukaan responden terhadap jenis makanan tersebut adalah susu. Meskipun susu dikategorikan sering dikonsumsi, namun frekuensi konsumsinya hanya sekitar 2 - $4 \mathrm{kali} /$ minggu sehingga dapat disimpulkan anak sekolah dasar lebih gemar mengonsumsi teh dibandingkan susu.

Pola konsumsi sumber makanan pelancar penyerapan zat besi menurut hasil penelitian ini menunjukkan hasil yang tidak berpengaruh secara bermakna terhadap kejadian anemia (nilai $\mathrm{p}>0,05$ ). Jenis bahan makanan pelancar absorbsi zat besi yang paling sering dikonsumsi adalah pisang $(12,5 \%)$ dengan nilai skor rata-rata 0,37 (dikonsumsi satu kali per minggu), berdasarkan kriteria pola konsumsi frekuensi konsumsi pisang belum dikatakan sering, sedangkan yang paling jarang dikonsumsi adalah jambu biji dan labu kuning $(84,2 \%)$. Tidak ada makanan yang dikonsumsi responden satu kali per hari. Meskipun bahan makanan absorbsi zat besi yang rata-rata bersumber dari sayur dan buah mudah didapatkan, konsumsi responden masih jarang karena responden lebih senang mengonsumsi makanan jajanan instan yang dijual di sekolah dan sekitar tempat tinggal dengan harga yang relatif murah dan disukai oleh anak-anak. Penelitian Briawan dkk, ${ }^{21}$ menunjukkan bahwa kadar $\mathrm{Hb}$ tidak berhubungan dengan asupan zat besi, bioavailabilitas zat besi dan asupan protein (nilai $\mathrm{p}>0,05$ ), dengan estimasi bioavailabilitas zat besi sebesar 1,09 miligram 
atau $10 \%$ yang termasuk dalam kategori sedang dan rata-rata kadar $\mathrm{Hb}$ siswi adalah sebesar 13,4 $\pm 1,4 \mathrm{~g} / \mathrm{dL}$.

Penelitian lainnya yaitu Vitolo,22 menujukkan pada anak usia $12-16$ bulan menunjukkan bahwa diet dengan bioavailabilitas besi yang tinggi melindungi anak-anak dari anemia sehingga dapat digunakan sebagai intervensi pada pelayanan kesehatan dasar.

\section{Kesimpulan}

Berdasarkan hasil penelitian yang telah dilakukan, dapat disimpulkan bahwa status kecacingan, kebiasaan sarapan pagi, pola konsumsi makanan sumber heme, dan pola konsumsi makanan penghambat zat besi merupakan faktor determinan kejadian anemia. Pola konsumsi makanan sumber heme dan sumber makanan penghambat zat besi merupakan determinan utama kejadian anemia gizi.

\section{Saran}

Kepada guru disarankan untuk memberikan penyuluhan kepada anak tentang pentingnya melakukan sarapan pagi sebelum ke sekolah dan meningkatkan pola konsumsi pangan yang banyak mengandung zat besi, seperti ikan, telur, kepiting, kerang serta sayur dan buah yang mudah di dapat di wilayah pesisir serta meningkatkan perilaku hidup bersih dan sehat di rumah dan di sekolah.

\section{Daftar Pustaka}

1. WHO. Worldwide prevalence of anemia 1993 - 2005, WHO global database on anaemia. Geneva: WHO library cataloguing-in-publication data; 2008

2. Arisman. Gizi dalam daur kehidupan. Jakarta: Penerbit Buku Kedokteran EGC; 2010.

3. Khomsan. Ekologi masalah gizi, pangan dan kemiskinan. Bandung: Alfabeta; 2012.

4. Kementerian Kesehatan Republik Indonesia. Riset kesehatan dasar (RISKESDAS) tahun 2013. Jakarta: Badan Penelitian dan Pengembangan Kesehatan Kementerian Kesehatan Republik Indonesia; 2013.

5. Nirmala D. Gizi anak sekolah. Jakarta: Penerbit Buku Kompas; 2012.

6. Cakrawati D, Mustika NH. Bahan pangan gizi dan kesehatan. Bandung: Alfabeta: 2012

7. Proverawati A, Misaroh. Manarche (menstruasi pertama penuh makna).
Yogyakarta: Muha Medika; 2009.

8. Kementerian Kesehatan Republik Indonesia. Pedoman gizi seimbang. Jakarta: Direktorat Jenderal Bina Gizi dan KIA; 2014.

9. Kisworini PMS, Triasih S. Anemia defisiensi besi: clinical pratice guidelling anemia defisiensi besi. Medika-Fakultas Kedokteran UGM, 2005; 39-81.

10. World Health Organization. Iron deficiency anaemia: assessment, prevention, and control: a guide for programme managers. Geneva: WHO; 2001.

11. Ibrahim, Anwar I. Ascariasis dan trichuriasis sebagai faktor penentu kejadian anemia gizi besi anak SD di permukiman kumuh Kota Makassar. Media Gizi Pangan. 2012; 8 (1): 48-54.

12. Kharis F, Marlinae L, Al Audhah N. Faktor-faktor yang berhubungan dengan kejadian kecacingan pada siswa Sekolah Dasar Negeri Cempaka 1 Kota Banjarbaru. Jurnal Epidemiologi dan Penyakit Bersumber Binatang. 2013; 4 (3): 121-7.

13. Favour O. A significant association between intestinal helminth infection and anaemia burden in children in rural communities of Edo state, Nigeria. North American Journal of Medical Sciences. 2011; 3 (1):30-4

14. Pergizi Pangan Indonesia. Prosiding peran pangan dan gizi dalam menyongsong era globalisasi. Jakarta: Pergizi Pangan Indonesia; 2010.

15. Tandirerung RU, Mayulu N, Kawengian SES. Hubungan kebiasaan sarapan pagi dengan kejadian anemia pada murid SD Negeri 3 Manado. Jurnal e-Biomedik (eBM). 2013; 1: 53-8.

16. Murphy JM. Breakfast and learning: an updated review. Current Nutrition \& Food Science. 2007; 3 (1): 3-36

17. Latifah MAO. Impact of breakfast eating pattern on nutritional status, glucose level, iron status in blood and test grades among upper primary school girls in Riyadh City, Saudi Arabia. Pakistan Journal of Nutrition. 2010; 9 (2): 106-11.

18. Pearson N, Stuart B, Trish G. Family correlates of breakfast consumption among children and adolescents. Appetite. 2009; 52: 1-7.

19. Abalkhail B, Shawky S. Prevalence of daily breakfast intake, iron deficiency anaemia and awareness of being anaemic among Saudi school students. International Journal Food Science Nutrition. 2002; 53 (6): 519-28.

20. Kementerian Kesehatan Republik Indonesia. Mengapa sarapan pagi itu penting? Jejaring informasi pangan dan gizi. Jakarta: Kementerian Kesehatan RI; 2010.

21. Briawan D, Adrianto Y, Ernawati D. Konsumsi pangan, bioavailibilitas zat besi dan status anemia siswi di Kabupaten Bogor. Prosiding Seminar Hasil-Hasil Penelitian. Bogor: IPB; 2012

22. Vitolo MR, Bortolini, GA. Iron bioavailability as a protective factor againts anemia among children aged 12 to 16 months. Jornal de Pediatria (RioJ). 2007; 83 (1): 33-8. 